\title{
EU Citizenship, Free Movement and Emancipation: A Rejoinder
}

\author{
Floris De Witte
}

\begin{abstract}
As was to be expected on a topic such as the relationship between free movement and Union citizenship, the discussion above has been both fruitful and wide-ranging, not in the least due to the decision of the British electorate to leave the EU that took place half-way through this EUDO forum debate (and that throws in doubt the rights of residence of Union citizens in the UK, as well as that of UK citizens in the EU). Rather than replying to the many interesting and insightful contributions individually, I will aim to address some of the themes that transcend the various points of view expressed. These are, in my view, three.
\end{abstract}

First, many commentators have suggested that my defence of Union citizenship as being primarily about free movement is insufficiently sensitive to its exclusionary potential. This exclusion may take place at Europe's borders (think of the refugee crisis), but also within the Member States, where free movement has been understood as being available primarily - and actually for the young, urban, educated elite. For those left behind - be it at Europe's borders or at home - free movement, on this account, is not a promise but a problem at the core of Union citizenship. The second theme that can be traced in the discussion is the effect that my understanding of free movement has on the state and its structures. On this view, construing Union citizenship as being centred on its capacity to discipline the nation state and its political processes through free movement creates a number of problems of its ownranging from the reconstruction of political participation to the destabilization of internal processes of solidarity and will-formation. The third and final theme that many commentators have picked up on, in different ways, is that understanding Union citizenship as being primarily about free movement offers (at best) a partial, inaccurate and normatively unattractive vision of what the individual European subject is. Union citizenship, on this account, ought to be about more than allowing individuals to escape their nation state and its political or normative preferences. 


\section{The exclusionary potential of free movement and Union citizenship}

In my initial contribution, I have defended the close link between free movement and Union citizenship on account that it liberates the individual from the shackles of majoritarian views 'at home', that it recalibrates ideas of justice in a more appropriate fashion, and that it is not premised on a vision of community that is exclusionary. Several commentators have emphasized that this vision is, however, also one that is selective. Sarah Fine highlights that while free movement might be a right that is available for EU citizens, it is also a reason for the creation of 'hard' external borders that attempt to keep out non-Europeans, who often find themselves stranded in terrible circumstances outside (or even inside) the EU. Kieran Oberman, likewise, points out that such closure on the EU-level simply recreates the problem that I am trying to overcome: it excludes outsiders, limits their emancipation and capacity to enjoy a range of rights.

Others, such as Rainer Bauböck, have emphasized that free movement (and therefore Union citizenship) prioritises the needs and aspirations of certain Europeans (let's say the well-educated, young, urban, and middleclasses) over those of other Europeans (in the traditional account, this group comprises of the elderly, the rural, working classes). This division, as is well documented, also appeared to lie at the core of the electoral split in the UK on Brexit. Julija Sardelić adds to this account that mobility requires certain social and cultural resources that are unavailable for whole swathes of the population. The differentiation that is implicit in free movement, on these accounts, jars with the basic premise of equality that is central to our understanding of citizenship.

Let me take these arguments in turn, starting with the exclusionary potential of free movement and Union citizenship in the most dramatic territorial - sense. Sarah Fine is certainly correct to highlight that the process of integration and its manifestation as Fortress Europe has dramatic consequences for those that cannot claim a right to free movement or Union citizenship. And certainly the institutions of the EU have placed a dodgy understanding of vulnerability at the core of its external border policy: one that understands the EU and its Member States to be vulnerable from intrusion by 'the other' as an object, rather than one that understands the refugees as the subject of vulnerability. This process can, possibly, indeed by reduced to the creation of a category of Union citizen that remains the main subject of the EU legal order, and main preoccupation of its institutional order, as Martin Ruhs claims. But the argument that reduces the drama 
unfolding at the Union's borders (and within the Union's borders) to a problem that is created by free movement and Union citizenship conflates two admittedly intertwined - processes.

Borders matter. Borders construct polities and engender certain relationships. And those relationships matter for the way in which we attribute rights and obligations. Many of us would not feel particularly inclined to share our resources with, say, a Russian oligarch. Most of us, conversely, would give up just about anything for the sake of our children or partner. Between these two extreme poles, our commitment to others depends on a range of factors - from the agapistic reflex that extreme suffering generates, to ideas of historical, ethnic, linguistic communities and from those revolving around sexual orientation, gender or political preferences to those created by shared institutional frameworks. On this relational account, the creation of the EU is, in its simplest form, the institutionalization of new relationships between citizens across borders. Something links the Polish national to the Belgian national that does not include their Ukrainian (or Australian, Ecuadorian, Senegalese) neighbour. The relationships generated by Union citizenship, in other words, must mean something - in my account primarily a shared commitment towards opening up national communities. That does not, of course, mean that non-EU citizens ought to be treated poorly, that they are somehow undeserving of protection, admission to the territory of the EU or help. What it does mean is that these are two conceptually separate discussions. The extent to which we defend or limit free movement of Union citizens, and the matter in which we construe internally the rights and obligations of those EU citizens based on their inter-personal relationship as institutionalized by EU citizenship, has little to do with how we treat those outside our borders of membership. Conditions, obligations, and rights of membership are bounded: they include members, and exclude non-members. This applies to book clubs, terrorist organisations, and transnational political communities. What we owe refugees fleeing war in atrocious and hazardous circumstances is a question that is distinct from the question what we owe fellow European citizens. The difference - which also explains why the former is so difficult to answer legitimately and authoritatively - is that one of these questions has been institutionalized, and the other has not: we have legal norms and institutional structures that translate the illdefined bond between Europeans into Union citizenship. And that institutionalization, in turn, is only possible once we accept that borders matter. Not as instruments to keep people out, but as instruments to solidify the relationships between those inside the borders. This also means that, contrary to Glyn Morgan's suggestion, if the UK were to leave the EU its citizens cannot remain Union citizens, and cannot derive rights and obligations under that heading. 
But the close link between free movement and Union citizenship has a second exclusionary effect - one that is internal to the EU. On this view, Union citizenship is an advantage for those willing and able to make use of it; but a disadvantage for those who cannot. On this narrative, the 'immobile' citizen faces increased competition for jobs and welfare resources from the 'mobile' citizen. Citizenship and free movement, then, create winners and losers - a process that became blatantly obvious in the Brexitvote. I would contest this argument both normatively and institutionally. The fact that only a portion of citizens actually make use of their right to free movement does not make the right any less important or relevant. A small proportion of the population makes use of their rights to free association or freedom of expression. Increasingly fewer people use their right to vote. Does that make these rights increasingly less relevant or important? Of course not. The same applies to free movement. The mere possibility of movement, legally guaranteed by free movement and Union citizenship, moreover, also has a reflexive virtue, as picked up by Vesco Paskalev (who highlights that younger Brits - regardless of their exercise of free movement - understand it to be a public good) and Saara Koikkalainen (who shows that 78 per cent of EU-wide respondents support free movement). The possibility of free movement liberates the self-understanding of the individual from the collective self-understanding of the polity they happen to be born in.

This does not mean that Union citizenship and free movement offer an equal opportunity of exercise to all Union citizens. As I will discuss below, the EU does not dispose of the institutional framework that can articulate and sustain such an understanding of substantive justice. To be sure, free movement presupposes certain social and cultural resources (if not necessarily those associated with the 'transnational elite' - it is hardly against these groups that the Brexit-vitriol was directed). What matters for our argument in this section, however, is not that free movement has high conditions of entry, but that it creates negative effects for those that do not make use of it (for whatever reason). This can be explained in one of two ways. First, and in the most important narrative in the Brexit campaign, it was suggested the EU migrants not only take jobs away from UK citizens, but also welfare resources, and create increased pressure on schools and hospitals. At the same time, every single piece of research that has taken place suggests that the UK benefits fiscally from free movement. How can these two positions be squared? It's very simple: by the decision of successive UK governments not to invest the fiscal windfall from free movement in additional welfare resources such as schools and hospitals. 
The other way of explaining the cleavage between pro-mobile and antimobile citizens is not to focus on the economics, but on identity politics. Rainer Bauböck, for example, refers to Theresa Kuhn's book in highlighting that individual experiences of transnationalism ('lived experience') makes them more pro-European and pro-free movement. On this view, it is to be expected that, say, Gibraltar, would vote in favour of staying in the EU with 96 per cent, while, say, Stoke-on-Trent would vote with 69.4 per cent against it. But that argument understands the idea of 'transnational experiences' much too narrowly. The 'Leave' voters in Stoke eat pizza and drink Stella Artois. The local pride - Stoke City football club - combines English players with Dutch, Austrian, Spanish, Italian and Irish stars. These kind of less obvious transnational experiences matter as they locate elements of 'the other' in something we consider our 'own'. The social capital built up through free movement extends much beyond instances of Erasmus or holidays abroad. It pervades our world.

But if both the economic and the sociological argument explaining the cleavage between pro-mobile and anti-mobile are at best oversold, how can we explain its indisputable emergence? The starting point in this analysis was intimated above - and that is that many of the citizens that have rejected the EU have indeed been 'left behind'. But the main culprit is their own government, not the EU. This is different, of course, in instances where the EU mandates welfare reform through its austerity drive. But blaming welfare scarcity in the UK on the EU seems a bit rich. Yet why do voters blame the EU and not the UK? This is where Brexit reveals a more structural problem for the EU, as I have discussed elsewhere ${ }^{1}$. It is because the EU cannot institutionalize contestation appropriately. In a well-functioning democracy, discontent that is so widely spread as the Brexit-cleavage is internalized in the system, and mediated through the politics of contestation. In such a system, political conflict feeds into the process of decision-making and stabilizes the overall project. Democracy, on this view, is a safety valve for emergent discontent. In the EU, on the other hand, the nature, conditions, and consequences of free movement cannot be contested. The only possible way to contest the normative orientation of the European market is to leave the EU. And so we see 'hard left' parties claiming that if we want to resist the neo-liberal nature of the EU, the only thing we can do is leave it. And so we have parties on the extreme right claiming that if we want to resist

1 Dawson, M and F. de Witte (2016), 'The Future of the EU between Independence and Interdependence', Verfassungsblog On Matters Constitutional, available at http://verfassungsblog.de/ the-future-of-the-eu-between-independence-and-interdependence/. 
immigration (for whatever reason), the only thing that we can do is leave the EU. If the EU doesn't start to think about how it can internalize and institutionalize contestation of its values, Union citizenship and free movement will indeed be seen as something that divides, that creates winners and losers. Not necessarily because it does create winners and losers, but because its contours and effects are not mediated through a process that can legitimize and explain the outcome.

\section{What Union citizenship and free movement do to the state}

A second theme that has emerged in the discussion is that my account of Union citizenship as 'anchorless' and as getting round the 'ethno-centric' vision of the nation state, on the one hand, underestimates the virtues of national institutional structures in solidifying inter-personal commitments and general will-formation and, on the other hand, underestimates the power of free movement as an instrument for cosmopolitan justice. These two points - made by Richard Bellamy and Kieran Oberman, respectively - suggest that my argument takes seriously neither the nation state nor cosmopolitanism. Instead, it is precariously perched between these two poles: free movement and non-discriminatory access to welfare benefits for EU migrants, on this account, are parasitical on domestic political commitments and extend them across borders without succeeding in fully disentangling them from the nation state and its structures. In simple terms, it destabilizes the nation state without replacing it with the promise of egalitarian cosmopolitanism. More is lost than gained in the exercise.

Richard Bellamy highlights that my argument is premised on the quest to create 'a fully fledged political and legal cosmopolitanism that looks to the ultimate demise of nation states as a necessary condition for justice'. He suggests that in doing so I misrepresent the state. The modern-day nation state is less exclusionary and more pluralist than I have presented it to be; and it is, crucially, indispensible for the determination, enforcement and stability of sharing practices. On the first point Bellamy is partially right: it is empirically demonstrable that membership to national political communities has never been more inclusive and pluralist. But this has clearly not affected the capacity for exclusionary and ethno-centric political narratives to control the political process - across the EU (and the US). It seems that the more diverse and inclusive our societies have become in terms of their membership, the less sensitive their politics become to diversity and inclusion of those that are not members. More inclusive membership thus does not equate to a pluralist society. On the second point Bellamy is completely right: the nation state remains absolutely indispensible in the determination, 
enforcement and stability of sharing practices and the processes of collective will-formation. My argument is not based on the rejection of the state and on the slow process towards a political cosmopolitanism. Instead, it is based on the realization that, given that the state and its institutional structures are indispensible for structuring authority in a legitimate fashion, we must be sensitive to its externalities. On this view, EU citizenship and free movement are not meant to obliterate the state; they are meant to limit the externalities of the institutional structure of the nation state. The first externality has been discussed at length in my initial post: that the nation state limits choices available for the citizen. The trade-off in liberal democracies is that in return for your chance to vote, you accept the majority position. Free movement cuts across this limit and offers Union citizens the choice of different visions of 'the good'.

The second and more structural externality, which Bellamy has picked up, is most easily explained if we pick up an element discussed above - that demands of justice are relational. As Païvi Johanna Neuvonen also reminds us, relationships between individuals that generate claims of justice or solidarity might take place within borders, but also across borders. The point that my initial contribution makes is essentially that while we have institutions that can make sense of the former type of relationships (namely, the domestic political process, that can mediate between competing claims of justice by insiders), it cannot possibly make sense of the relationships across borders. Imagine an Irish woman living in France and working in Belgium. What does the social relationship between her and French society mean in terms of justice? What does Belgium 'owe' her because of her economic participation in the Belgian market? Allowing the French or Belgian political system to answer these questions creates a democratic problem, as our Irish women (and therefore her relational position vis-à-vis nationals) are not included in its determination. This is where and how free movement and Union citizenship, and particularly through the principle of nondiscrimination based on nationality serve to more appropriately settle questions of justice and democracy. Union citizenship and free movement respect the institutional structures of the nation state in the determination and enforcement of questions of justice. As far as EU law is concerned, the Austrian decision to have free tertiary education is as 'just' as the UK's decision to charge $£ 9,000$ per year. This respect for national choices is indeed, as Bellamy highlights, necessary for its stability. What free movement law does is simply extend that decision to include those Union citizens who have a sufficiently strong relationship with the host state - be it through economic or social interactions. As such, free movement and Union citizenship do not serve to substitute for the nation state and its structures, they serve, instead, 
to recalibrate questions of justice in a fashion that is more sensitive to the relationships across border that the EU has engendered, to which the nation state is structurally blind.

This idea of Union citizenship as supplementing national citizenship can, of course, be deduced from the text of the Treaty. It also means that Union citizenship and free movement are not codifications of a sort of cosmopolitanism as suggested by Kieran Oberman. Free movement, on my account, is not a good per se. It is a good because of the way in which it recalibrates domestic processes of will-formation and sharing - not because it seeks to replace or subvert them. It creates emancipatory potential for individuals exactly because they can navigate between existing institutional articulations of justice and 'the good life'. Without those institutional structures of the nation state, free movement and equal treatment is pointless. Being equally entitled to nothing, after all, entitles you to nothing. This leads to me to the final point that I made in my initial contribution. The way in which Union citizenship and free movement attempt to internalize relationships across borders within domestic institutional structures is normatively appealing exactly because it piggy-backs on those domestic structures. There is no need for the articulation of a European form of 'being' that can integrate and structure its own idea of community and political form. EU citizenship is, in a sense, agnostic.

\section{A normative vision for Union citizenship}

The final theme that has come through the discussion is that this link between free movement and citizenship that is central in my account makes for a normatively and institutionally impoverished vision of justice. This critique comes in many flavours. Daniel Thym highlights that the Court's ruling in Dano, for example, demonstrates the absence of a robust or 'thick' principle of justice in the Court's understanding of what free movement and Union citizenship mean. More broadly, he argues that even if free movement once constituted the core of a normatively ambitious idea of what it means to be a European citizen; the Union has now lost constitutional confidence, and has become more deferential to domestic ideas of belonging, sharing and justice. What is needed, then, is a thicker vision of social justice that engages all Europeans, whether they move or not. Criticism of this lack of a more coherent and nuanced idea of justice can also be traced in other contributions. Johanna Païvi Neuvonen suggests that the normative centrality of free movement understands the subject as atomistic and unencumbered - which makes for a narrow, individualistic, and, ultimately, not particularly emancipated, self. Emancipation, after all, requires the capacity to encounter the 'other' as 
part of the construction of the self. Vesco Paskalev argues that the ease of movement across borders destabilizes another element that is crucial to justice and citizenship: that of (equal) political participation and engagement. On these accounts, free movement does not suffice. Union citizenship should be about more than simply free movement if it is to be normatively appealing. I broadly agree on these points, in so far as they indicate that Union citizenship offers a partial vision of justice at best. It does not set out a vision of substantive justice for 500 million Europeans. It does not deal well with instances of discrimination that transcend borders, as Julija Sardelić reminds us.

The problem is that Union citizenship can never offer more than a partial vision of justice unless we recreate on the European level the institutional preconditions that we find on the national level (and that I have argued in favour of above). To use the example mentioned above: is it more 'just' to fund tertiary education through general taxation or make the student pay himself? If we have a fiscal windfall of $€ 400$ million, should we spend it on healthcare, pensions, or education? These questions can only legitimately be answered if they are discussed and mediated through a 'thick' democratic institutional structure - of which the EU is a very very distant cousin. The EU simply does not possess the institutional structure required to answer the question: 'what is it to be European?' or 'what do we Europeans owe each other'. And this institutional incapacity leaves us in a double bind: national political processes are sufficiently 'thick', but structurally exclude relationships across borders from consideration. European political processes are too thin to articulate a substantive vision of justice for all 500 million Europeans. What we are left with is the legal norms of free movement and EU citizenship that seek (and not always succeed) to figure out what these relationships across borders mean in terms of justice. The idea of justice in the EU, in a sense, is tiered: it depends on both national institutional structures and transnational legal norms. Free movement and Union citizenship, then, as Païvi Johanna Neuvonen forcefully argues in her comment and her recent book, may not be sufficient to achieve justice in the EU - but they are necessary. Unless and until the EU develops its institutional structure in a way that is more sensitive to the views of its citizens, this is as good as it gets.

The institutional implication of this argument is that the scope and limits of free movement and Union citizenship cannot be decided through political structures as they currently are. Martijn van den Brink has argued that the Union legislator offers a democratic - if not particularly ambitious - vision on what free movement means, and the Court in Dano was right in accepting this vision. Union citizenship, in his view, is not a normative commitment towards emancipation and the limitation of state power, but its opposite: an 
expression of state power. Member States, acting together in the Council, have the right to decide when and under which conditions free movement is possible, and to decide what the limits of EU citizenship ought to be. This argument underestimates the level of institutional sophistication that is required for a system to be able to 'translate' inter-personal relational claims of justice and solidarity into a legitimate and enforceable system of rights and obligations. As Richard Bellamy has highlighted as well, the institutional presuppositions for this task cannot be found beyond the nation state. The EU lacks thick representative, deliberative and participatory elements, it lacks the support cast of integrated political parties, civil society, grassroots movements, transnational media that allow for inter-personal communication about the question: 'how do we want to live together in this social space?' 'What do we owe each other by virtue of our shared participation in the EU?'. The Union legislator cannot possibly get the answer to these questions 'right'. So we are left in an institutional situation where these incipient, partial, and ill-defined bonds and relationships between Europeans, created by transnational economic, social, political and cultural links cannot be articulated by either national legislatures or their European counterparts. Ill-equipped as the Court may be to makes sense of these new relationships, it is the only institution that can make good on its premise: that it must mean 'something' to be a Union citizen beyond what it means to be a national of a Member State.

Open Access This chapter is licensed under the terms of the Creative Commons Attribution 4.0 International License (http://creativecommons.org/licenses/by/4.0/), which permits use, sharing, adaptation, distribution and reproduction in any medium or format, as long as you give appropriate credit to the original author(s) and the source, provide a link to the Creative Commons license and indicate if changes were made.

The images or other third party material in this chapter are included in the chapter's Creative Commons license, unless indicated otherwise in a credit line to the material. If material is not included in the chapter's Creative Commons license and your intended use is not permitted by statutory regulation or exceeds the permitted use, you will need to obtain permission directly from the copyright holder. 